\title{
Effects of Using Consciousness-Raising Tasks on Iranian Intermediate EFL Learners' Self-Efficacy and Autonomy in Speaking
}

\author{
Hadi Salehi (Corresponding author) \\ English Department, Najafabad Branch, Islamic Azad University, Najafabad, Iran \\ Email: hadisalehi1358@yahoo.com \\ Batoul Beigi Rizi \\ English Department, Najafabad Branch, Islamic Azad University, Najafabad, Iran
}

Received: $24 / 08 / 2020$

Accepted: 10/12/2020

Published: 01/01/2021

Volume: 2 Issue: 1

How to cite this paper: Salehi, H. (2021). Effects of Using Consciousness-Raising Tasks on Iranian Intermediate EFL Learners' Self-Efficacy and Autonomy in Speaking. Journal of Critical Studies in Language and Literature, 2(1), 1-12

DOI: https://doi.org/10.46809/jcs1l.v2i1.47

Copyright (C) 2020 by author(s) and Global Talent Academy Ltd. This work is licensed under the Creative Commons Attribution International License (CC BY 4.0).

http://creativecommons.org/licenses/by/4.0/

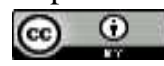

\begin{abstract}
This study investigates different methods for improving speaking skill and compares using traditional methods with using consciousness-raising (CR) tasks. The aim of this study was three fold: (i) to explore whether using CR tasks can improve Iranian EFL learners' speaking skill in terms of self-efficacy, (ii) to examine whether using CR tasks can improve Iranian EFL learners' speaking skill in terms of autonomy, and (iii) to explore Iranian EFL learner' attitudes towards the effects of using CR tasks on their speaking skill in terms of self-efficacy and autonomy. To achieve these aims, 30 L2 learners studying English at Payam Persa language institute in Zarinshahr were selected, after taking part in an Oxford Quick Placement Test (OQPT), as the participants of the study. They were subsequently divided into two groups of equal size in order to obtain the required data. The study was a quasi-experimental one, which employed a pretest-treatment-posttest design. The experimental group (EG) was exposed to the treatment (i.e., Consciousness-Raising), while the control group (CG) was taught based on the pattern drill practice and traditional methods. The required data were obtained from a Face to Face Oral Placement Test (FFOPT), speaking pretest/posttest, speaking self-efficacy questionnaire, and speaking autonomy questionnaire. The findings showed that using CR tasks had significant effects on the learners' self-efficacy. Furthermore, using CR tasks had a significant effect on the autonomy of the learners. In addition, the participants had significantly positive attitudes towards using CR tasks for the purpose of speaking self-efficacy and speaking autonomy in language class. The use of CR tasks has many pedagogical benefits for the teachers and they are enjoyable among the EFL learners.
\end{abstract}

Keywords: Autonomy, Consciousness-Raising, Fluency, Self-efficacy, Speaking, Tasks

\section{Introduction}

According to Sénéchal, Lefevre, Thomas, and Daley (1998), becoming a competent speakers would cause augmented skill in reading and writing as language users become more and more proficient. As Britton (1993) maintained, it so expressively that "reading and writing float on a sea of talk" (p. 11). As an essential tool for language teaching and learning, speaking can "facilitate language acquisition and development" (Burns \& Goh, 2012, p. 15), and it can be advantageous for learners' academic achievement along with professional success (Saunders \& O’Brien, 2006). 
In order to realize why some learners are successful while others are not successful enough in achieving their goals, second language (L2) scholars have inspected learners' perception of the issues that affect L2 achievement. The learners' sense of self-efficacy has a key role in their learning style (Li, 2017). Learner's feelings have the same influence on their learning success as their styles and strategies do (Ehrman, 1996). Bandura (1997) maintained that self-efficacy is a type of cognition.

Theory and research advocate the belief that it can affect other aspects of growth (e.g., social, emotional, behavioral) and that is influenced by a number of personal, social, and contextual variables. In this study, self-efficacy undoubtedly is influenced by CR tasks. The changes in self-efficacy as learners develop have important imputations for their class performances (Urdan \& Pajares, 2006). Self-efficacy is not acquired by learning how to succeed; it is acquired learning from one's mistakes and how to proceed when one does not accomplish. Successful teachers develop self-efficacy by helping students regard mistakes as positive provisions of subsequent achievement (Fry, Ketteridge, \& Marshall, 2008).

Autonomy is another important factor. The term autonomy goes backward to ancient Greek philosophy where it was used to define a political state. This meaning was later adjusted by Enlightenment philosophers like Immanuel Kant. From this standpoint, language learners are believed to be in need of guidance and support because of the role they take in the context of language instruction (Thouësny, 2011). It is necessary for the development of autonomy that learners become conscious of themselves as learners-aware, for instance, of the learning techniques they unconsciously favor and qualified to judge how operative those techniques are (Swarbrick, 2002).

In improving these affective factors in speaking, there are activities in which the learners are expected to use the target language in order to attain a specific result within a particular situation (e.g. solving a problem; planning a meeting; selecting candidates for an interview) (Tomlinson, 2011). It seems possible that these results are because of CR that is one available method, which agrees for students to cooperatively, improve their speaking by means of tasks. Stevick (1990) explained one purpose of tasks in humanistic methods: some of the exercises used by those methods urge students to verbalize to "share" with one another their ideas and feelings on numerous topics. At times, these topics are somewhat personal, but advocates contend that their very imminence and urgency enable the class to reach beyond a simple quest for linguistic proficiency and to develop pride, self-confidence, and a sense of community (Tomlinson, 2007).

It can be noted that speaking is a very important skill and the development of this skill among EFL learners requires employing new methods of teaching. Therefore, an attempt was made in this study to explore whether using CR tasks can improve Iranian EFL learners' speaking skill in terms of self-efficacy and autonomy and their attitudes toward it. To achieve the aims of the study, the following research questions were posed:

i) Does using CR tasks have any significant effect on improving Iranian EFL learners' speaking skill?

ii) Does using CR tasks have any significant effect on improving Iranian EFL learners' speaking skill in terms of selfefficacy?

iii) Does using CR tasks have any significant effect on improving Iranian EFL learners' speaking skill in terms of autonomy?

iv) What are the Iranian EFL learners' attitudes towards the effects of using CR tasks on their speaking skill in terms of self-efficacy and autonomy?

\section{Literature Review}

\subsection{Consciousness-Raising (CR)}

Twenty-five years ago, Language Awareness (LA) was put forward, primarily by modern linguists, as a new 'bridging' element in the UK school curriculum. It was viewed as a solution to several of the failures in UK schools: illiteracy in English, failure to learn foreign languages, and divisive prejudices (Hawkins, 1999). CR which is known as awarenessraising is part of the process a learner can go through with new language. Learners first become familiar with nature of the new language, then identify and distinguish it, then produce it. CR is for L2 learners and is intended to facilitate a move from the explicit to the implicit (Andrews, 2007). Two of the most instrumental cognitive processing approaches, which elucidated SLA studies, are Sharwood Smith's CR and Schmidt's Noticing Hypothesis (Sharwood Smith, 1993). The term CR exhibits an intentional attention to be devoted to the formal properties of language which aims at improving the development of second language knowledge. The "noticing hypothesis" states that what learners consider in input is what becomes intake for learning (Heift \& Schulze, 2007).

The term CR is related to the deliberate attempt to attract the learners' attention particularly to the formal characteristics of the target language and it aims at attracting the learners' attention to the existing gap between their interlanguage system and the native speakers' rules of the foreign language. In CR approach, learners can organize their interlanguage system, and it simplifies the process of noticing, theorizing how language functions, and structuring the knowledge of language system. Ellis (2002) also believes that CR can be presented to the learners inductively or deductively. In his standpoint, inductive way is such a method that the learners are provided with some data, then they are required to originate a rule to explain the grammatical aspect and a deductive way is such a method that the students are provided with an explicit rule, then they are asked to do some tasks (Fatemipour \& Hemmati, 2015). Ellis 2003 (p. 16) stated that a task is intended to "result in language use that bears resemblance, direct or indirect, to the way language is used in real word."

CR tasks are also rational from Schmidt's (2012) viewpoint, as CR can assist learners in building explicit knowledge concerning the target language (TL), and it is this explicit knowledge that Eckerth (2008) and Schmidt propose may ease 
noticing. Contrary to Krashen's (1985) acquisition/learning dichotomy, where the roles of explicit instruction and conscious learning are modulated, much practical evidence in SLA literature indicates that noticing plays a significant role in L2 enhancement, at least for some linguistic knowledge, if not all. Altman (1997, p. 93), from her personal language learning case study, found that, "a key to the success of the language learner seems to be the extensive employment of awareness-the focusing of attention on all aspects of the language to be learned". Some authors clarify the term CR by relating it to other fields of teaching, explicit teaching of grammar, language awareness, language acquisition and practice. It has been stated that CR refers to attracting learners' attention considering particular grammar structures. Therefore, it is primarily an approach to show how the target language functions. Learners would be expected to observe the features of the target language because of this awareness raising (Al-Jardani, 2012). In categorizing the teaching method that can accommodate learners' needs, the features of CR should be further investigated. CR highlights explicit explanation from teacher who prioritizes learners' self-discovery of the rules and presents target form in an attention drawing manner. Above all, it endorses learners' awareness of the target form, which as stated by Schmidt (1990) is the earlier and indispensable phase of learning. Schmidt (1990) believes that before learners can learn anything, they have to be aware of first of what they are learning, pay attention to it, and notice it (Idek, Fong, \& Sidhu, 2013).

Vygotsky founded consciousness as "the objectively observable organization of behavior that is imposed on humans through participation in sociocultural practices" (Norris, 2004, p. 157). Vygotsky also argued that human consciousness is achieved by the internalization of shared social behavior. Unlike the predominant model of children's learning that sees the function of learning as acquisition of knowledge, Vygotsky's (1986) theory of the zone of proximal development (ZPD) stresses the importance of the educative process rather than the final outcome. The ZPD is the difference between existing and potential levels of development revealed through an analysis of how far a student is able to master a task by themselves or with help from a more knowledgeable other such as a teacher or more capable peer. Vygotsky's concept of the ZPD defines the potential development of a child rather than an abstract metaphor for learning. For Vygotsky, real learning is that which is in advance of development and is mediated through interactions with other people and through the social and cultural acquisition of sign systems. The ZDP indicates both the presence of maturing psychological functions and the possibility of meaningful interventions that stimulate conceptual development. This process of conceptual development involves co-operation and collaboration between the teacher and the learner, or between learners at different levels of development. For Vygotsky, collaboration and co-operation are 'crucial features of effective teaching'. Vygotsky also argued that learning takes place when the learning task is set at a level in advance of the student's current mental level of development. This has task design implications for the classroom teacher concerning the relationship between instruction and pupil development and the classroom environment (Thompson, 2014).

2.2. Self-efficacy

One of the features that affect language learning is learner's self-efficacy which was first introduced by Bandura in 1977. For him, self-efficacy theory is one facet of social cognitive theory. Social cognitive theory suggests that people are able to standardize and reflect on themselves and to actively influence their environments. Bandura (1995) defined self-efficacy as a specific type of expectancy related to a person's beliefs in his/her ability to carry out a specific action or series of actions required to produce a result. He later extended this definition. In Bandura (1995), self-efficacy is explained as people's beliefs about their own abilities to control events which may touch their lives, and their beliefs in their abilities to combine the motivation, cognitive resources, and other necessary actions to control task demands. According to this definition, it can be comprehended that self-efficacy is not concerned with the skills people have to do a task, but with judgments of what they can do with those possessed skills. Efficacy does not refer to a static ability that people possess or do not possess; rather, Bandura (1995) stated that it is "a generative capability in which cognitive, social, emotional and behavioral subs kills must be organized and effectively orchestrated to serve innumerable purposes" (pp. 36-37). He highlighted that having a skill is different from being able to use it or to include it into a proper course of action in order to use it efficiently in different situations. High self-efficacy beliefs result in goal-oriented actions on the part of the learner and have a reproductive capability; they force learners to try more in pursuit of their goals, and make them more confident in the face of problems and difficulties. High levels of self-efficacy in a specific domain have been related to high levels of achievement in that domain (Tabrizi \& Saeidi, 2015).

Graham (2011) also related self-efficacy to individuals' ideas in their capacity to achieve particular tasks, assumed to have a considerable effect on levels of continuation and the choices that people make. Concerning the importance of selfefficacy, Bandura (1986) considered self-efficacy to have an important role in language learning by promoting or hindering learners' progress. In this vein, Bandura (1986) proposed that self-efficacy is more powerful than knowledge, skill, and prior achievement (Baleghizadeh \& Masoun, 2014).

Bandura (1997) summarized sources of self-efficacy into four categories, namely, mastery experience, physiological reactions, vicarious experience and social persuasion. In connection with mastery experience, performances understood as effective increase of self-efficacy while consequences identified as failure decrease self-efficacy. Physiological reactions such as heartbeats, tiredness and nervousness can reduce one's self-efficacy. Vicarious experiences change one's selfefficacy by means of observation of how similar tasks are performed by other people. Social persuasion is concerned with feedback and information from other people which influence individuals' belief in their own capabilities. Positive responses from students and colleagues advocate teacher self-efficacy while negative feedback, criticism and neglect lessen teacher self-efficacy. Moreover, the power of social persuasion depends on the proficiency and experience of the person involved. 
Researchers such as Bandura (2006) and Pajares (1997) stated that self-efficacy influences people's perceptions of environmental conditions and obstacles, their choice of activities, and the amount of effort they devoted to an activity, and their persistence when faced with difficulties. Bandura (1997) found that self-efficacy had significant impact on human achievement in education, health, sports, and work. In educational settings, self-efficacy has been validated as an important influence on not only students' achievement, but also teachers' performance (Yeung, Chen, \& Li, 2015).

\subsection{Autonomy}

Learners' autonomy plays a significant role in both second language acquisition and foreign language learning. The development of learners' autonomy, which refers to the ability to control one's own social environments and activities, has been commonly considered the foremost intention of academic programs. The notion of learner autonomy goes together with other individual learner features (Valizadeh, 2016).

In line with that, pursuant to Masouleh and Jooneghani (2012), the term autonomy has produced significant argument, in as much as linguists and educationalists have failed to conclude an agreement concerning what autonomy really is. In effect, it is contended that autonomy in language learning could be thought of as a required purpose for philosophical, pedagogical, and practical reasons (Hosseinzadeh \& Baradaran, 2015).

Purkey and Novak (1984, p. 13) believe that "good teaching is the process of inviting students to see themselves as able, valuable, and self-directing and of encouraging them to act according to these self-perceptions". Benson (2013, p. 6) defined autonomy as "whatever an autonomous person thinks it is". In other words, learners who progress towards autonomy can develop the ability to assess their accuracy (Aydin, 2014). According to Chan (2016), autonomous learners should have the ability and responsibility to decide the goals of learning, define the learning content and progress, choose the appropriate methods to learn, monitor their learning process, and finally, evaluate the learning outcome

\subsection{Studies Related to the Issue}

Haidara (2014) described the psychological factor that has a negative effect on the English speaking performance for the English learners in Indonesia. A descriptive qualitative design was employed to conduct this research. The research was consisted of theoretical review, field notes, observations, and unstructured interviews. The researcher stated that the most common factors that affect students' English speaking performance are (1) fear of making mistakes, (2) feeling shy, (3) feeling hesitated, (4) and lack of confidence while speaking English.

Salehi, Ebrahimi, Sattar, and Shojaee (2015) examined the relationship between degrees of learner autonomy and the use of strategies for coping with speaking problems and the learners' success in their speaking classes. To verify the degree of correlation among degree of learner autonomy, use of strategies for coping with speaking problems, and success in speaking classes, a validated questionnaire was given to 50 participants. The participants were asked to self-report the strategies they use when they have problems during speaking English and to report their degree of learner autonomy as an EFL learner by selecting one of the items provided in the questionnaire. The analysis of the obtained results revealed that learners whose speaking grades were low were weaker than the learners whose speaking grades were high during the use of strategies to deal with speaking problems in general.

Mohammadi and Safdari (2015) investigated the effect of online mobile-assisted task-based activities on improving Iranian intermediate EFL learner' speaking skills. To this end, 90 intermediate language learners whose ages ranged between 13 to 16 years were selected and assigned to three interactive, non-interactive, and conventional groups. The results revealed that learners in the interactive group performed better than the ones in the face-to-face group regarding their speaking skills.

Davies (2015) investigated the role that voice microblogging-based activities play in improving learners' spoken production skills. The study involved 33 low-intermediate level university students whose major was English at a private university in Japan. Findings, based on an exploratory factor analysis coupled with group interviews, suggest that tasks using Bubbly are beneficial for students' oral performance as they help to provide extra practice for speaking.

\section{Methodology}

\subsection{Participants}

The participants of this study were 15 male and 15 female intermediate EFL learners whose ages range between 15 and 23 years old. They were studying English in Payam Persa Language Institute located in Zarrinshahr, Isfahan, Iran. All participants were native speakers of Farsi. The participants were selected conveniently in this study. However, they were randomly assigned into two equal groups of experimental and control in terms of the number of the participants in each group.

\subsection{Instruments}

\subsubsection{Oxford Quick Placement Test (OQPT)}

Oxford Quick Placement Test (OQPT) was used to ascertain the homogeneity of the participants in terms of language proficiency and to make sure that all participants were intermediate EFL learners. The test consists of 60 multiple-choice items and the test taker's level is evaluated by the number of the questions they answer correctly. The test was divided into two parts: one part (Questions 1-40) dealt with grammar and vocabulary items that referred to all participants. Part two (Questions 41-60) was answered by the participants who finished the first part properly.

3.2.2. Speaking Pretest and Posttest 
The speaking section of Face to Face Oral Placement Test (FFOPT), consisting of 12 questions, was employed as the pretest in this study. Each interviewee had to respond to general questions about herself/himself on the topics such as jobs, family, sport, hobby, etc.

Next, there was another two-minute interaction during which the test takers had to interact together on a visual stimulus. They had to use functional language to talk about rules and obligations in their jobs, family, etc. They had to use functional language to make suggestions and respond to them, to make recommendations, and to negotiate agreements. A card of a color photograph was given to each of the candidates in turn as a verbal prompt to talk about a particular topic up to a minute. During these three minutes, the participants were assessed on their photograph describing, managing discourse, and using appropriate vocabulary in a longer turn. All photographs used in this phase were related to the same topic. The last threeminute discussion of speaking part of FFOPT was a general conversation. The participants talked with each other in this phase on the topic established on the theme of last part. Their discussion was about their opinions, experiences, likes/dislikes, habits, preferences, etc. The final scores of test takers were utilized to ensure the homogeneity of control and experimental groups, with regard to their speaking ability, before the beginning of the treatment. Meanwhile, it should be note that two raters scored the speaking test. Based on the EUPT speaking scale, the subjects were scored by the interlocutor, who conducted the speaking test. From 0-20 on their global achievement. (0-3 = appropriateness, $0-4=$ Adequacy of vocabulary for the purpose, $0-4=$ Grammatical accuracy, and 0-3 = intelligibility, $0-3=$ Fluency $0-3$, relevance and adequacy of content). The sum of the ratings for each individual was considered as her total score on the speaking test.

By the tenth session of the study, the same speaking test was given to the participants as the posttest when the four sessions of the treatment were ended. It should be noted that the first session was used to test the subjects of the study.

\subsubsection{Speaking Self-efficacy Questionnaire}

In order to measure the participants' self-efficacy in speaking, the researchers used a questionnaire which was originally adopted from Jinks and Morgan (1999). However, some modifications were made on the original draft to modify it based on the study. The modified version was also checked in terms of its reliability using Chronboch's Alpha. This questionnaire consisted of 25 five-point Likert type items ranging from "strongly disagree" to "strongly agree". In this questionnaire, 1 represented 'strongly disagree' and 5 represented 'strongly agree'.

\subsubsection{Speaking Autonomy Questionnaire}

The autonomy scale selected for this study was an autonomy questionnaire of speaking skills adopted from Buendía Arias (2015). It is a questionnaire with 25 items that aims to examine the autonomy of language learners in speaking and the items are answered on a 5-point Likert scale.

\subsubsection{A Researcher-made Questionnaire}

A researcher-made questionnaire, which included 15 close-ended items, was used to examine the students' motivation and attitude towards CR. There were five alternatives for each item which ranged from strongly disagree to strongly agree. It seems necessary to mention that the independent variable in this study was CR tasks and dependent variable was learners' speaking.

\subsection{Procedure}

In the first step, the OQPT was conducted to ensure the participants' homogeneity in both experimental and control groups. Then, in order to obtain the required data on the three variables (i.e., self-efficacy, autonomy, and speaking ability), the self-efficacy and autonomy questionnaires were chosen as the instruments for the collection of data, and speaking proficiency test was administered as pretest in both groups. In the second phase, CR tasks as treatment were performed for the participants of the experimental group. Finally, the posttest, the self-efficacy questionnaire, and autonomy questionnaire were administered in both experimental and control groups. In the last part of the study, a questionnaire was developed by the researcher and its validity was checked by three experts. Then, by the use of Cronbach's Alpha, the reliability of the questionnaire was calculated which was 0.88 . After making sure of the validity and reliability of the questionnaire, the researcher distributed the questionnaire among the students who used CR tasks and explained how they should to fill out the questionnaire. Gathering the questionnaires, the researcher examined them one by one to collect necessary data for analyzing.

The researcher aimed to develop learners' awareness of strategies through consciousness-raising in the experimental group. The control group did not receive the strategies awareness-raising session, but simply they performed the two identical role-playing speaking tasks without review. In addition, they were free from instructional intervention. To maximize condition equivalence, neither group was informed of the topic or task in advance. Both groups were engaged in a 10- to 20minute reflection in class, but the members of the experimental group were asked to reflect specifically on their strategy use and members of the control group were asked to reflect freely on their execution of the speaking activity. The members of the experimental group also were asked to complete a post-speaking activity reflection on their strategy use through a Strategy Recall Checklist.

\section{Results}

\subsection{Answer to the First Research Question}

As it was stated above, the first research question was "Does using CR tasks have any significant effect on improving Iranian EFL learners' speaking skill in terms of self-efficacy?" To uncover the difference between these two groups regarding their speaking, their speaking pretest scores could be compared via an independent-samples $t$ test, to make sure 
they were not drastically different with respect to the variable under investigation at the outset of the study. An independentsamples $t$ test could also be used to compare the EG and CG learners' speaking scores after the experiment was completed. However, to control any possible pre-existing differences between the two groups and then compare their posttests accordingly, one-way ANCOVA was conducted. Table 1 shows the descriptive statistics related to this analysis:

Table 1: Descriptive Statistics for Comparing the Speaking Posttest Scores of the EG and CG Learners

\begin{tabular}{cccc}
\hline Groups & Mean & Std. Deviation & $N$ \\
\hline CG & 22.21 & 4.08 & 15 \\
\hline EG & 30.29 & 1.93 & 15 \\
\hline Total & 26.25 & 5.17 & 30 \\
\hline
\end{tabular}

Such descriptive statistics as mean and standard deviation are shown for both CG and EG learners in Table 1. The speaking posttest mean score of the CG learners $(M=22.21)$ was found to be smaller than the speaking posttest mean score of the EG learners $(M=30.29)$. To determine whether this difference was a statistically significant one or not, the researcher had to look down the Sig (2-tailed) column in the ANCOVA table below:

Table 2: Results of One-Way ANCOVA for Comparing the Speaking Posttest Scores of the EG and CG Learners

\begin{tabular}{ccccccc}
\hline Source & Type III Sum of Squares & $d f$ & Mean Square & $F$ & \multicolumn{2}{c}{ Sig. Partial Eta Squared } \\
\hline Corrected Model & 508.32 & 2 & 254.16 & 25.62 & .00 & .65 \\
\hline Intercept & 612.19 & 1 & 612.19 & 61.71 & .00 & .69 \\
\hline Pretest & 18.68 & 1 & 18.68 & 1.88 & .18 & .06 \\
\hline Groups & 443.13 & 1 & 443.13 & 44.67 & .00 & .62 \\
\hline Error & 267.82 & 27 & 9.91 & & & \\
\hline Total & 21453.28 & 30 & & & & \\
\hline Corrected Total & 776.15 & 29 & & & & \\
\hline
\end{tabular}

In Table 2, if you find Groups in the leftmost column and read across this row, under the Sig. column, you can find the $p$ value, which should be compared with the pre-set significance level (which is .05). The $p$ value here was smaller than the specified level of significance $(.00<.05)$, indicating that there was a statistically significant difference between the EG and CG learners' posttest speaking scores. This means that the treatment (i.e. using CR tasks) brought about a significant difference in the speaking skills of the learners exposed to it. Under Partial Eta Squared, the value across the Groups row was .62 , which shows that being in EG or CG accounted for $62 \%$ of the variance in the posttest speaking scores of the learners. The comparison of the CG and EG learners' posttest speaking scores could be graphically seen in Figure 1 below:

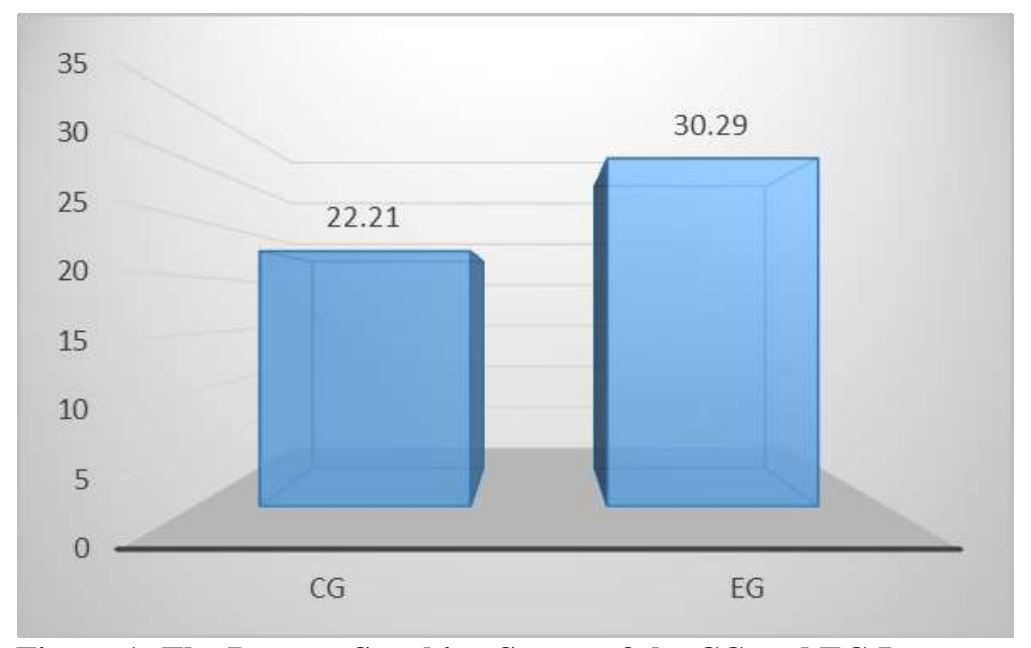

Figure 1: The Posttest Speaking Scores of the CG and EG Learners

As it is clearly seen in Figure 1, there was a considerable difference between the CG and EG learners on the posttest of speaking, where the latter could obtain a significantly higher mean score than could the former.

4.2. Answer to the Second Research Question

It might be recalled that the second research question of the study was: Does using CR tasks have any significant effect on improving Iranian EFL learners' speaking skill in terms of self-efficacy? To answer this question, the CG and EG 
learners' post-experiment self-efficacy scores were compared via a one-way ANCOVA, the results of which are shown in Table 3 and Table 4.

Table 3: Descriptive Statistics for Comparing the Posttest Self-Efficacy Scores of the CG and EG Learners

\begin{tabular}{cccc}
\hline Groups & Mean & Std. Deviation & $N$ \\
\hline CG & 58.93 & 6.29 & 15 \\
\hline EG & 86.13 & 10.61 & 15 \\
\hline Total & 72.53 & 16.27 & 30 \\
\hline
\end{tabular}

Table 3 shows that the post-experiment self-efficacy mean score of the EG learners $(M=86.13)$ turned out to be larger than the post-experiment self-efficacy mean score of the CG learners $(M=58.93)$. To find out whether this difference was statistically significant or not, the researcher had to consult the ANCOVA table.

Table 4: Results of One-Way ANCOVA for Comparing the Posttest Self-Efficacy Scores of the CG and EG Learners

\begin{tabular}{ccccccc}
\hline Source & Type III Sum of Squares & $d f$ & Mean Square & $F$ & Sig. & Partial Eta Squared \\
\hline Corrected Model & 5803.51 & 2 & 2901.75 & 41.72 & .00 & .75 \\
\hline Intercept & 4837.39 & 1 & 4837.39 & 69.54 & .00 & .72 \\
\hline Pretest & 254.71 & 1 & 254.71 & 3.66 & .06 & .11 \\
\hline Groups & 3163.54 & 1 & 3163.54 & 45.48 & .00 & .62 \\
\hline Error & 1877.95 & 27 & 69.55 & & & \\
\hline Total & 165514.00 & 30 & & & & \\
\hline Corrected Total & 7681.46 & 29 & & & & \\
\hline
\end{tabular}

In Table 4, the $p$ value in front of Groups was found to be smaller than the specified level of significance $(.00<.05)$, which means that there was a statistically significant difference between the CG and EG learners on their posttest selfefficacy scores. In other words, the treatment (i.e. using CR tasks) exerted a significant difference on the feelings of selfefficacy of the learners in the CG and EG in favor of the latter group of learners. Under Partial Eta Squared, the value across the Groups row was .62, which means that being in CG or EG accounted for $62 \%$ of the variance in the posttest self-efficacy scores of the learners. Figure 2 shows this significant difference between the CG and EG learners on their post-experiment self-efficacy scores:

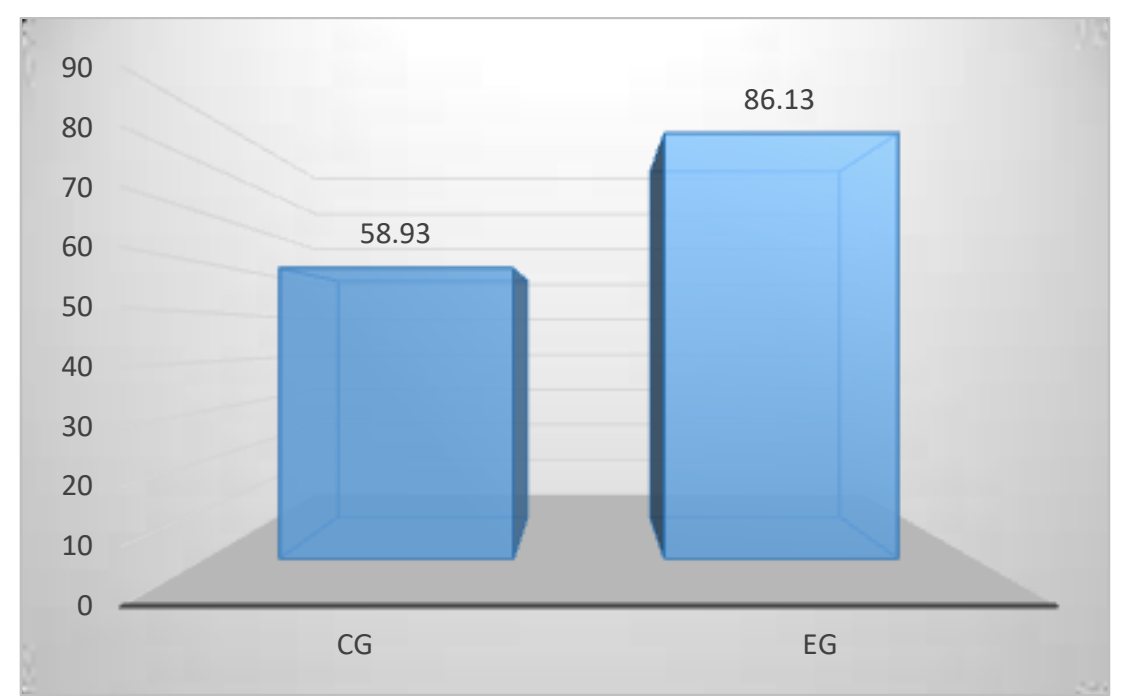

Figure 2: The Posttest Self-Efficacy Scores of the CG and EG Learners

Figure 2 depicted that the EG learners managed to outperform CG counterparts significantly on the posttest of selfefficacy.

4.3. Answer to the Third Research Question

As the third research question of the study was "Does using CR tasks have any significant effect on improving Iranian EFL learners' speaking skill in terms of autonomy?" the answer to this research question was found in the same way the previous research questions were answered (i.e., the CG and EG learners' post-experiment autonomy scores were compared via a one-way ANCOVA). The results of this statistical analysis are shown in Tables 5 and 6 below: 
Table 5: Descriptive Statistics for Comparing the Posttest Autonomy Scores of the CG and EG Learners

\begin{tabular}{cccc}
\hline Groups & Mean & Std. Deviation & $N$ \\
\hline CG & 52.13 & 22.45 & 15 \\
\hline EG & 65.33 & 9.68 & 15 \\
\hline Total & 58.73 & 18.26 & 30
\end{tabular}

As Table 5 shows, the post-experiment autonomy mean score of the EG learners $(M=65.33)$ was found to be higher than the post-experiment autonomy mean score of the CG learners $(M=52.13)$. In order to see if this difference was statistically significant or not, the researcher needed to check the ANCOVA table below:

Table 6: Results of One-Way ANCOVA for Comparing the Posttest Autonomy Scores of the CG and EG Learners

\begin{tabular}{ccccccc}
\hline Source & Type III Sum of Squares & $d f$ & Mean Square & $F$ & Sig. & Partial Eta Squared \\
\hline Corrected Model & 1313.90 & 2 & 656.95 & 2.12 & .00 & .13 \\
\hline Intercept & 4063.66 & 1 & 4063.66 & 13.11 & .00 & .32 \\
\hline Pretest & 7.10 & 1 & 7.10 & .02 & .06 & .00 \\
\hline Groups & 1211.57 & 1 & 1211.57 & 3.91 & .00 & .12 \\
\hline Error & 8365.96 & 27 & 309.85 & & & \\
\hline Total & 113168.00 & 30 & & & & \\
\hline Corrected Total & 9679.86 & 29 & & & & \\
\hline
\end{tabular}

It could be seen in Table 6 that the $p$ value in front of Groups was lower than the specified level of significance $(.00<$ .05 ), indicating that there was a statistically significant difference between the CG and EG learners on their posttest autonomy scores. Differently put, the treatment (i.e. using CR tasks) had a significant effect on the autonomy of the learners in the EG. Under Partial Eta Squared, the value across the Groups row was .12, which means that being in CG or EG was responsible for $12 \%$ of the variance in the posttest autonomy scores of the learners. Figure 3 shows graphically that the EG learners enjoyed a significantly higher level of autonomy than did the CG learners on the posttest:

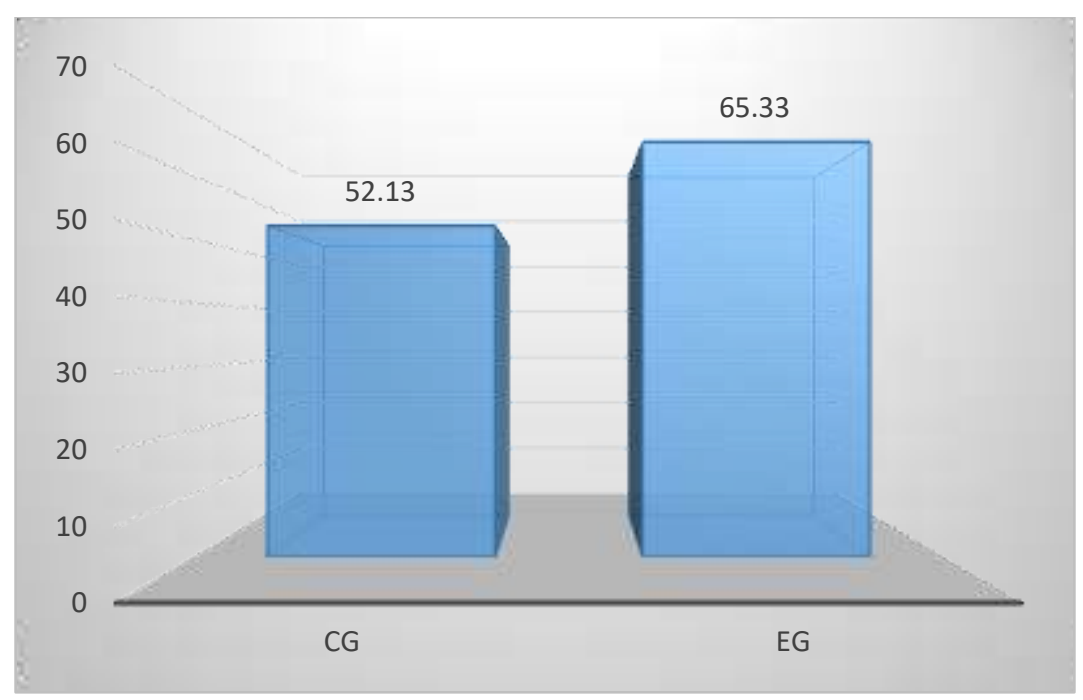

Figure 3: The Posttest Autonomy Scores of the CG and EG Learners

It is clearly seen that the EG learners could significantly outperform their CG counterparts on the posttest of autonomy. 4.4. Answer to the Fourth Research Question

Finally, in the fourth research question, the aim was to uncover the attitudes of the EG learners towards the treatment they received (i.e. the CR tasks). The results of the analysis of the data obtained through the questionnaire are summarized in the table below:

Table 7: Results of the Attitude Questionnaire

\begin{tabular}{lcccccc}
\hline \multicolumn{1}{c}{ Statements } & $\begin{array}{c}\text { Strongly } \\
\text { agree }\end{array}$ & Agree & $\begin{array}{c}\text { No } \\
\text { opinion }\end{array}$ & Disagree & $\begin{array}{c}\text { Strongly } \\
\text { disagree }\end{array}$ & Mean \\
\hline $\begin{array}{l}\text { 1. CR tasks make speaking more } \\
\text { enjoyable and more interesting. }\end{array}$ & 2 & 7 & 3 & 2 & 1 & 3.46 \\
\hline 2. CR tasks increase the & 3 & 5 & 3 & 2 & 2 & 3.33 \\
\hline
\end{tabular}




\begin{tabular}{|c|c|c|c|c|c|c|}
\hline $\begin{array}{l}\text { 3. CR tasks are some activities } \\
\text { which can be used for different } \\
\text { topics. }\end{array}$ & 1 & 6 & 5 & 2 & 1 & 3.26 \\
\hline $\begin{array}{l}\text { 4.CR tasks made me really } \\
\text { interested in learning language in } \\
\text { general and learning grammar in } \\
\text { particular. }\end{array}$ & 4 & 2 & 6 & 2 & 1 & 3.40 \\
\hline $\begin{array}{l}\text { 5. CR tasks develop the learners' } \\
\text { speaking ability to a great extent. }\end{array}$ & 0 & 8 & 4 & 3 & 0 & 3.33 \\
\hline $\begin{array}{l}\text { 6. CR tasks are user-friendly } \\
\text { activities. }\end{array}$ & 6 & 6 & 2 & 1 & 0 & 4.13 \\
\hline $\begin{array}{l}\text { 7. CR tasks are authentic } \\
\text { materials. }\end{array}$ & 1 & 5 & 8 & 1 & 0 & 3.40 \\
\hline $\begin{array}{l}\text { 8. CR tasks keep attention longer } \\
\text { during speaking skill. }\end{array}$ & 3 & 3 & 7 & 1 & 1 & 3.40 \\
\hline $\begin{array}{l}\text { 9. CR tasks help me save a lot of } \\
\text { time and energy. }\end{array}$ & 1 & 4 & 5 & 4 & 1 & 3.00 \\
\hline 10. I enjoyed using CR tasks a lot & 0 & 6 & 6 & 2 & 1 & 3.13 \\
\hline $\begin{array}{l}\text { 11. CR tasks inspired me a lot to } \\
\text { learn English. }\end{array}$ & 2 & 5 & 3 & 3 & 2 & 3.13 \\
\hline $\begin{array}{l}\text { 12. CR tasks improved my } \\
\text { vocabulary as well as grammar } \\
\text { knowledge a lot. }\end{array}$ & 2 & 7 & 3 & 1 & 2 & 3.40 \\
\hline $\begin{array}{l}\text { 13. My speaking ability has been } \\
\text { improved through my vocabulary } \\
\text { enhancement by the use of } \\
\text { speaking. }\end{array}$ & 6 & 4 & 3 & 1 & 1 & 3.86 \\
\hline $\begin{array}{l}\text { 14. CR tasks helped me to be a } \\
\text { knowledgeable person by } \\
\text { increasing vocabulary knowledge. }\end{array}$ & 2 & 2 & 10 & 1 & 0 & 3.33 \\
\hline $\begin{array}{l}\text { 15. CR tasks improved my } \\
\text { speaking fluency to a large extent. }\end{array}$ & 0 & 6 & 5 & 3 & 1 & 3.06 \\
\hline
\end{tabular}

In this questionnaire, as it could be seen, all of the mean scores of the questionnaire items were above 3.00 (which is the average value of the choices when strongly agree receives 5 and strongly disagree receives 1 ), which indicated the learners' agreement with the statements (or positive attitudes about the CR tasks). The total mean score obtained from the questionnaire items, as is shown in Table $\mathbf{8}$, is 3.37. To see if this degree of having positive attitudes is statistically large/significant or not, the $p$ value in the one-sample $t$ test table should be examined:

Table 8: One-Sample t Test Results for the Learners' Attitudes

\begin{tabular}{|c|c|c|c|c|c|c|}
\hline \multicolumn{7}{|c|}{ Test Value $=3$} \\
\hline \multirow[t]{2}{*}{$t$} & \multirow[t]{2}{*}{$d f$} & \multirow{2}{*}{$\begin{array}{c}\text { Sig. } \\
\text { (2- } \\
\text { tailed) }\end{array}$} & \multirow{2}{*}{$\begin{array}{c}\text { Overall } \\
\text { Questionnaire Mean }\end{array}$} & \multirow{2}{*}{$\begin{array}{c}\text { Mean } \\
\text { Difference }\end{array}$} & \multicolumn{2}{|c|}{$\begin{array}{l}\text { 95\% Confidence Interval of the } \\
\text { Difference }\end{array}$} \\
\hline & & & & & Lower & Upper \\
\hline 4.96 & 14 & .000 & 3.37 & .37 & .21 & .53 \\
\hline
\end{tabular}

Since the $p$ value in this table is lower than the significance level $(.000<.05)$, it could be understood that the EG learners held significantly positive attitudes towards the treatment (that is, using CR tasks) for the purpose of speaking self-efficacy and speaking autonomy in language classes.

\section{Discussion}

CR tasks have positive effects on improving EFL learners' different language skills. CR or drawing learners' attention to the formal properties of language, facilitates language learning effectively (Bialystok, 1992). Consciously attending to and noticing specific aspects of the target language are the first things in learning (Leow, 2000; Schmidt, 1993).

The findings of the study are in line with the previous studies regarding the implementation of consciousness-raising tasks to increase learners' consciousness in language learning. For instance, Mohamed (2004) investigated learners' perspectives of 
the effectiveness of CR tasks. The findings show that CR tasks (both deductive and inductive) are helpful learning tools to enhance learners' awareness of linguistic forms. In another study, Fatemipour and Hemmati (2015) evaluated the applicability of three CR tasks containing three techniques of at a specific vocational college. This study revealed that the nature of CR leads learners to be aware of their learning process of the target language. Iskandar and Heriyawati (2015) examined the implementation of grammar CR activities for the students' grammatical competence. This study suggested that implementing grammar consciousness-raising activities could make students aware of language forms that encourage them to learn language. In all of these studies, the leaners' language competence was significantly improved by the use of CR activities in the class which supports the findings of the current study.

High levels of self-efficacy are associated with good performance in language learning tasks in different (Farjami \& Amirian, 2013). Considering the issue that students with higher degrees of self-efficacy exert greater effort in order to perform the required tasks (Pajares, 2003). Since self-efficacy can be strengthened or weakened by the results of personal efforts and by input from the environment (Schunk \& Pajares, 2009), CR tasks provide necessary factors that improve EFL learner's self-efficacy in speaking. The purpose of CR tasks is to increase learners' awareness of grammatical forms and their properties without necessarily emphasizing production which is reached through the process of noticing (Schmidt, 1990). The declarative knowledge of form means to know the formal properties of a form and to be able to retain form-meaning relationship. It is obvious when learners can retain this relationship their self-efficacy in speaking is improved and they can have a better judgment of how well they perform in speaking situations and activities. Moreover, CR tasks can facilitate acquisition of correct and sufficient explicit knowledge of forms. Knowledge of forms plays a significant role in the improvement of EFL learners' speaking and enabling them to have an accurate evaluation of their speaking (Schunk \& Pajares, 2009). Therefore, CR tasks by improving learners' explicit knowledge of forms can have an important effect on EFL learners' self-efficacy in speaking.

Training autonomous speakers are the ultimate goal of most language teaching programs. Therefore, applying the activities that satisfy this desire is considered utmost importance. If learners are supposed to be autonomous speakers, they need to become completely familiar with the structure of speaking skill (McColl, 1992). CR tasks concentrate on production which leads to better and more complete understanding of the structure by learners (Ellis, 2002). In addition, Willis (1996) purports that a CR task can be seen as a guided problem-solving task where learners are encouraged to notice the target form, draw conclusions from what they notice and to make the network of their beliefs about language based on the conclusion they draw. Because of these features of CR tasks, they can be effective in improving EFL learners' autonomy in speaking. This vantage point is confirmed by the results of the present study because the participants who were exposed to CR tasks acquired more autonomy in speaking.

The findings of the study that indicated the participants had positive attitudes toward CR tasks are in line with some previous studies. For example, Mohamed (2004) investigated the EFL learners' perspective of CR tasks. He stated that learners consider tasks useful in imparting new knowledge about the language. Their responses indicated that the tasks are effective learning tools because they enable them to become familiar with different structures of the language. Moreover, Amirian and Abbasi (2014) and Amirian and Sadeghi (2012) maintained that CR tasks make a great enthusiasm in EFL learners for learning English. As previously mentioned, CR tasks play a significant role in improving EFL learners' awareness of language and language skills. Raising the awareness of the subject facilitates the process of learning by the learners and consequently makes learners more interested in learning English.

\section{Conclusion}

Based on the obtained results of the study, it can be maintained that learning speaking via CR tasks is more effective and beneficial than traditional approaches; though, the effect of traditional approaches cannot be overlooked. Moreover, using CR in this approach is an active process encouraging students to find the features and structure of the speaking skill rather than teaching of them explicitly. In addition, because these positive effects of CR tasks they can be very effective in enhancing EFL learners' self-efficacy and autonomy in speaking. Therefore, it is highly recommended that EFL teachers implement CR task in their classes to assist their students in improving their speaking skill and their self-efficacy and autonomy in speaking. However, these tasks should not be used as the main method of teaching; instead, they should be used as the assistance of traditional methods of teaching speaking.

The results of the study will be useful for both English instructors and curriculum designers in the field of TEFL. English teacher can implement these tasks in their classes to boost their learners' speaking skill in general and their self-efficacy and autonomy in speaking in specific. Curriculum designers can put these activities in their curricula to facilitate teaching the speaking skill for English teachers and enabling EFL learners to become more autonomous speakers and more competent in self-efficacy in speaking.

\section{References}

Al-Jardani, K. S. S. (2012). English language curriculum evaluation in Oman. International Journal of English Linguistics, 2(5), 40-52. 
Altman, R. (1997). Oral production of vocabulary. In J. Coady \& T. Huckin (Eds.), Second language vocabulary acquisition (pp. 69-97). Cambridge, the United Kingdom: Cambridge University Pres.

Amirian, S. M. R., \& Abbasi, S. (2014). The Effect of Grammatical Consciousness-Raising Tasks on Iranian EFL Learners' Knowledge of Grammar. Procedia-Social and Behavioral Sciences, 98, 251-257.

Amirian, S. M. R., \& Sadeghi, F. (2012). The effect of grammar consciousness-raising tasks on EFL learners performance. International Journal of Linguistics, 4(3), 708-720.

Andrews, S. (2007). Researching and developing teacher language awareness. In J. Cummins \& C. Davison (Eds.), International handbook of English language teaching (pp. 945-959). New York, NY: Springer.

Aydin, S. (2014). The Use of Blogs in Learning English as a Foreign Language. Mevlana International Journal of Education (MIJE), 4(1), 244-259.

Baleghizadeh, S., \& Masoun, A. (2014). The effect of self-assessment on EFL learners' self-efficacy. TESL Canada Journal, $31(1), 42-58$.

Bandura, A. (1986). Social foundations of thought and action: A social cognitive perspective. Englewood Cliffs, NJ: Princeton-Hall.

Bandura, A. (1995). Self-efficacy in changing societies. Cambridge, the United Kingdom: Cambridge University Press.

Bandura, A. (1997). Self-efficacy: The exercise of self-control. New York, NY: Freeman.

Bandura, A. (2006). Guide for constructing self-efficacy scales. Self-Efficacy Beliefs of Adolescents, 5(1), $307-337$.

Benson, P. (2013). Teaching and researching: Autonomy in language learning. London, United Kingdom: Routledge.

Bialystok, E. (1992). Attentional control in children's metalinguistic performance and measures of field independence. Developmental Psychology, 28(4), 654-664.

Britton, J. (1993). Language and learning: The importance of speech in children's development. Portsmouth, NH: Cook Publishers, Inc.

Buendía Arias, X. P. (2015). A comparison of Chinese and Colombian university EFL students regarding learner autonomy. Profile Issues in Teachers Professional Development, 17(1), 35-53.

Burns, C., \& Goh, C. C. M. (2012). Teaching speaking: A holistic approach. New York, NY: Cambridge University Press.

Chan, H. W. (2016). Popular Culture, English Out-of-Class Activities, and Learner Autonomy among Highly Proficient Secondary Students in Hong Kong. Universal Journal of Educational Research, 4(8), 1918-1923.

Davies, R. J. (2015). Why Tweet When You Can Bubble? Students' Perceptions of a Voice Microblog for the Development of Their L2 Spoken Production Skills. JALT CALL Journal, 11(3), 213-233.

Eckerth, J. (2008). Investigating consciousness-raising tasks: pedagogically targeted and non-targeted learning gains. International Journal of Applied Linguistics, 18(2), 119-145.

Ehrman, M. E. (1996). Understanding second language learning difficulties. Thousand Oaks, CA: Sage.

Ellis, R. (2002). Grammar teaching-practice or consciousness-raising. In J. C. Richards (Ed.), Methodology in language teaching: An anthology of current practice (pp. 167-174). Cambridge, the United Kingdom: Cambridge University Press.

Ellis, R. (2003). Task-based Language Learning and Teaching. Oxford, The United Kungdom: Oxford Applied Linguistics.

Farjami, H., \& Amirian, M. (2013). Relationship between EFL learners' perceived social self-efficacy and their foreign language classroom anxiety. Journal of English Language Teaching and Learning, 4(10), 77-103.

Fatemipour, H., \& Hemmati, S. (2015). Impact of Consciousness-Raising Activities on Young English Language Learners' Grammar Performance. English Language Teaching, 8(9), 1-10.

Fry, H., Ketteridge, S., \& Marshall, S. (2008). A handbook for teaching and learning in higher education: Enhancing academic practice. London, United Kingdom: Routledge.

Haidara, Y. (2014). Psychological Factor Affecting English Speaking Performance for the English Learners in Indonesia. Universal Journal of Educational Research, 4(7), 1501-1505.

Hawkins, E. W. (1999). Foreign language study and language awareness. Language Awareness, 8(3-4), $124-142$.

Heift, T., \& Schulze, M. (2007). Errors and intelligence in computer-assisted language learning: Parsers and pedagogues. New York, NY: Routledge.

Hosseinzadeh, E., \& Baradaran, A. (2015). Investigating the Relationship between Iranian EFL Teachers' Autonomy and Their Neuro-Linguistic Programming. English Language Teaching, 8(7), 68-75.

Idek, S., Fong, L. L., \& Sidhu, G. K. (2013). The Use of Consciousness-Raising Tasks in Learning and Teaching of SubjectVerb Agreement. English Language Teaching, 6(6), 113-122.

Iskandar, J., \& Heriyawati, D. F. (2015). Grammar Consciousness-raising Activities and their Impact on Students' Grammatical Competence. JEELS, 2(1), 62-77.

Jinks, J., \& Morgan, V. (1999). Children's perceived academic self-efficacy: An inventory scale. The Clearing House, 72(4), 224-230.

Krashen, S. D. (1985). The input hypothesis: Issues and implications. Addison-Wesley Longman Ltd.

Leow, R. P. (2000). A study of the role of awareness in foreign language behavior. Studies in Second Language Acquisition, 22(4), 557-584.

Li, K. (2017). Motivational Regulation in Foreign Language Learning. New York, NY: Springer. 
Masouleh, N. S., \& Jooneghani, R. B. (2012). Autonomous learning: A teacher-less learning! Procedia-Social and Behavioral Sciences, 55, 835-842.

McColl, H. (1992). Achieving student autonomy in speaking through the use of interactive video. Language Learning Journal, 5(1), 25-26.

Mohamed, N. (2004). Consciousness-raising tasks: A learner perspective. ELT Journal, 58(3), 228-237.

Mohammadi, M., \& Safdari, N. (2015). Pedagogical values of mobile-assisted task-based activities to enhance speaking skill. In 2015 EUROCALL Conference (pp. 416-420).

Norris, S. (2004). Analyzing multimodal interaction: A methodological framework. London, United Kingdom: Routledge.

Pajares, F. (1997). Current directions in self-efficacy research. Advances in Motivation and Achievement, 10, 1-49.

Pajares, F. (2003). Self-efficacy beliefs, motivation, and achievement in writing: A review of the literature. Reading \&Writing Quarterly, 19(2), 139-158.

Purkey, W. W., \& Novak, J. M. (1984). Inviting school success: A self-concept approach to teaching, learning, and democratic practice (2nd ed.). Belmont, CA: Wadsworth.

Salehi, H., Ebrahimi, M., Sattar, S., \& Shojaee, M. (2015). Relationship between EFL Learners' Autonomy and Speaking Strategies They Use in Conversation Classes. Advances in Language and Literary Studies, 6(2), 37-43.

Saunders, W. M., \& O’Brien, G. (2006). Oral language. In F. Genesee, K. Lindholm-Leary, W. M. Saunders, \& D. Christian (Eds.), Educating English language learners: A synthesis of research evidence (pp. 14-63). Cambridge, England: Cambridge University Press.

Schmidt, R. (1990). The role of consciousness in second language learning. Applied Linguistics, 11(2), 129-158.

Schmidt, R. (1993). Consciousness, learning and interlanguage pragmatics. Interlanguage Pragmatics, $21,42$.

Schmidt, R. (2012). Attention, awareness, and individual differences in language learning. In W. M. Chan, K. N. Chin, S. Bhatt, \& I. Walker (Eds.), Perspectives on individual characteristics and foreign language education (6th ed., pp. 2750). Boston, MA: De Gruyter Mouton.

Schunk, D. H., \& Pajares, F. (2009). Self-efficacy theory. In K. R. Wentzel \& A. Wigfield (Eds.), Handbook of motivation at school (pp. 35-53). New York, NY: Routledge.

Sénéchal, M., Lefevre, J., Thomas, E. M., \& Daley, K. E. (1998). Differential effects of home literacy experiences on the development of oral and written language. Reading Research Quarterly, 33(1), 96-116.

Sharwood Smith, M. (1993). Input enhancement in instructed SLA. Studies in Second Language Acquisition, 15(2), $165-179$.

Stevick, E. W. (1990). Humanism in language teaching: A critical perspective. Cary, NC: Oxford University Press.

Swarbrick, A. (2002). Teaching modern languages. London, United Kingdom: Routledge.

Tabrizi, H. M., \& Saeidi, M. (2015). The relationship among Iranian EFL learners' self-efficacy, autonomy and listening comprehension ability. English Language Teaching, 8(12), 158-169.

Thompson, I. (2014). Designing tasks in secondary education: Enhancing subject understanding and student engagement. London, United Kingdom: Routledge.

Thouësny, S. (2011). Dynamically Assessing Written Language: To what Extent Do Learners of French Language Accept Mediation? In S. Thouësny \& L. Bradley (Eds.), Second language teaching and learning with technology: Views of emergent researchers (pp. 169-188). Dublin, Irland: Research-publishing. net.

Tomlinson, B. (2007). Language acquisition and development: Studies of learners of first and other languages. London, United Kingdom: A\&C Black.

Tomlinson, B. (2011). Materials Development in Language Teaching. Cambridge, England: Cambridge University Press.

Urdan, T., \& Pajares, F. (2006). Selfefficacy beliefs of adolescents. Greenwich, CT: Information Age Publishing.

Valizadeh, M. (2016). Iranian EFL Students' Emotional Intelligence and Autonomy in Distance Education. English Language Teaching, 9(10), 22-30.

Vygotsky, L. S. (1986). Thought and language (rev. ed.). Cambridge, MA: MIT Press.

Willis, J. (1996). A flexible framework for task-based learning: An overview of a task-based framework for language teaching. In J. Willis \& D. Willis (Eds.), Challenge and change in language teaching (pp. 52-62). Melbourne, Australia: Macmillan Education Australia.

Yeung, A. S., Chen, Z., \& Li, B. (2015). Maximizing the benefit of technology for language learning. In K. Caroline (Ed.), Motivation, Leadership and Curriculum design (pp. 185-199). New York, NY: Springer. 